26 Spector TD, Thompson SG. The potential and limitations of meta-analysis. I Epidemiol Community Health 1991;45:89-92.

27 Davey Smith G, Shipley MJ, Marmot MG, Patel C. Lowering cholesterol concentrations and mortality. BMf 1990;301:552.

28 Pekkanen J, Nissinen A, Punsar S, Karvonen MJ. Serum cholesterol and risk of accidental or violent death in a 25-year follow-up: the Finnish cohorts of the seven countries study. Arch Intern Med 1989;149:1589-91.

29 Law MR, Thompson SG. Low serum cholesterol and the risk of cancer: an analysis of the published prospective studies. Cancer Causes and Control 1991;2:253-61

30 Davey Smith G, Shipley MJ, Marmot MG, Rose G. Plasma cholesterol concentration and mortality: the Whitehall study. FAMA 1992;267:70-6.

31 The Multiple Risk Factor Intervention Trial Research Group. Mortality rates after 10.5 years for participants in the multiple risk factor intervention trial. Findings related a priori hypothesis of the trial. FAMA 1990;263:1795-801.

32 Holme I, Hjermann I, Helgeland A, Leren P. The Oslo study: diet and antismoking advice. Additional results from a 5-year primary preventive trial in middle-aged men. Prev Med 1985;14:279-92.

33 Kornitzer M, Rose G. WHO European collaborative trial of multifactorial prevention of coronary heart disease. Prev Med 1985;14:272-8.

34 Strandberg TE, Salomaa VV, Naukkarinen V, Vanhanen HT, Sarna SJ,

Miettinen TA. Long term mortality after 5-year multifactorial primary Miettinen TA. Long term mortality after 5-year multifactorial primary
prevention of cardiovascular diseases in middle-aged men. FAMA 1991;266: prevention.

35 Oliver MF. Might treatment of hypercholesterolaemia increase non-cardiac mortality? Lancet 1991;337:1529-31.
36 Lipid Research Clinics Program. The Lipid Research Clinics' primary prevention trial results. FAMA 1984;231:351-64.

37 Joint Formulary Committee. British National Formulary. London: British Medical Association and Pharmaceutical Press, 1990.

38 Wysowski DK, Kennedy DL, Gross TP. Prescribed use of cholesterolysowski DK, Kennedy DL, Gross TP. Prescribed use of cholesterollowering drugs in th 2185-8

39 Taylor WC, Pass TM, Shepard DS, Komaroff L. Cholesterol reduction and life expectancy. Ann Intern Med 1987;106:605-14.

40 Browner WS, Westenhouse J, Tice JA. What if Americans ate less fat? FAMA 1991;265:3285-91

41 Goldman L, Weinstein MC, Goldman PA, Williams LW. Cost-effectiveness of HMG-CoA reductase inhibition for primary and secondary prevention of coronary heart disease. FAMA 1991;265:1145-51.

42 Kristiansen IS, Eggen AE, Thelle DS. Cost-effectiveness of incremental programmes for lowering serum cholesterol concentration: is individual prevention worth while?. BMF 1991;302:1119-22.

43 Schmieder RE, Rockstroh JK, Messerli FH. Antihypertensive therapy. To stop or not to stop? FAMA 1991;265:1566-71.

44 Jones PH. Lovastatin and simvastatin prevention studies. Am $f$ Cardiol 1990;66:39-43B.

45 Gordon DJ. Trials of HMG CoA reductase inhibitors. In: National Heart Lung and Blood Institute, ed. Conference on low blood cholesterol levels: disease associations. Bethesda: National Institutes of Health, 1990:45-7.

(Accepted 15 October 1991)

\title{
Medicine in Europe
}

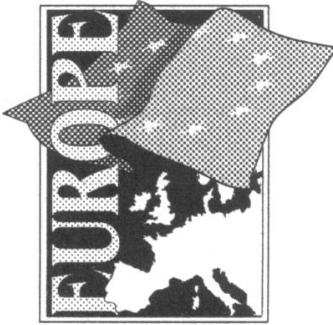

This is the 10th in a series of articles looking at medical

\section{A common ethics for a common market?} issues in Europe.

\section{Søren Holm}

Inevitably the growing economic and political integration in Europe will lead to attempts to integrate the legal rules and the paralegal regulations, declarations, and statements that govern medical ethics. There have already been some moves in this direction.

The main institutions on the European scene are the Commission of the European Community, the European Parliament, the Council of Ministers of the European Community, and the Council of Europe. The last of these is a non-EC body of which all democratic states in the European region are members.

The Council of Europe has been the most active, through resolutions in its committee of ministers and its parliamentary assembly and through its standing committee of experts in bioethics. Medical ethical questions fall outside the scope of the Treaty of Rome unless they coincide with questions concerning consumer protection or other market related issues. This explains the relatively limited involvement of the EC in the field. The Council of Ministers has, however, recently issued a series of statements on AIDS. This anticipates the probable inclusion of health and social issues in the coming treaty on European union.

All these official bodies issue statements, declarations, and directives with widely different legal status. * They are supplemented by powerful but less official bodies like the Standing Committee of Doctors of the EC and the Roman Catholic Congregation for the Doctrine of Faith. Researchers interested in medical ethics have also formed the European Society for Philosophy of Medicine and Health Care and the European Association of Centres of Medical Ethics.

\section{When in doubt form a committee}

A consistent feature of the debates about medical

The Centre for Social Ethics and Policy, University of Manchester, and Department of Medicine, Esbjerg Central Hospital, DK-6700 Esbjerg, Denmark Søren Holm, MA, senior house officer ment on specific policy proposals whereas others have been divided. Most have been single issue ad hoc bodies, but some countries-for example, France and Denmark-have established permanent ethical councils. ${ }^{23}$

Apart from their stated objectives of fact finding and policy making such commissions fulfil a variety of other political purposes. ${ }^{4}$ So it is likely that the same approach will be chosen at the European level, initially in the form of ad hoc committees and perhaps later as permanent organisations. But it is doubtful that such commissions can represent the full width of the cultural diversity in the EC. The Glover working party on reproductive technologies authorised by the commission managed to reach a consensus, but its seven members did not represent the full diversity of the EC.

\section{Abortion, IVF, and embryo research}

Almost every European country has had its own commission on abortion, in vitro fertilisation, and embryo research, and these have been supplemented by the Congregation of the Doctrine of Faith, ${ }^{6}$ the Glover working party, ${ }^{5}$ and by the standing committee of experts in bioethics (CAHBI). ${ }^{7}$ The guidelines proposed vary from the relatively liberal to the conservative. The resulting legislation is also divergent, ${ }^{8}$ and it is difficult to see how a common European policy could be established. The commission took no action after the Glover report and it is unlikely that any action will be taken.

\section{Genetic screening}

European guidelines for the use of genetic information do not exist, although the EC has allocated resources for research on the ethical issues created by the use of genetic information in the general genome research programme. ${ }^{9}$ During the planning phase of this programme the emphasis was changed from "prediction" to "medical importance" because of sustained criticism of the programme's ethical basis. ${ }^{10}$ Research on germ line treatment and somatic cell treatment was deleted from the programme. The future guidelines will probably be rather restrictive. 
The parliamentary assembly of the Council of Europe endorses a "right to a genetic inheritance which has not been artificially interfered with" as a basic human right in its recommendation 934(1982) and proposes the establishment of a list of severe diseases for which genetic treatment is warranted.

\section{Confidentiality of medical records}

The rules concerning access to medical records vary in the different member states. In some countries patients have a right to access, in others the records are the exclusive property of doctors. The discussion in the official European bodies has mainly concentrated on securing confidentiality when new technology is used. The Council of Ministers is preparing a general directive concerned with confidentiality of personal information but this directive is still under negotiation. The Council of Europe has issued a recommendation on the impact of new technologies on health services, which states that protection of confidentiality must be secured in all systems.

\section{Testing for HIV}

The Council of Ministers of the EC,,$^{112}$ the committee of ministers of the Council of Europe, the general assembly of the World Health Organisation, and the Standing Committee of Doctors of the EC have issued statements on AIDS that underline the importance of voluntary testing and strict confidentiality. They emphasise that any discrimination against people who are HIV positive is an unacceptable infringement of human rights.

It is, however, difficult to ensure full confidentiality when access to testing for HIV becomes more widespread. In Denmark a private firm has already advertised a do it yourself test. They send out a blood collecting device and analyse the blood sent back. The amount of blood needed is small and there is no way of checking that the person requesting the test is the person whose blood is being tested.

\section{Organ donation}

Organ donation systems also differ. Most countries have an opting in system where donors have to state their willingness to donate, but some countriesBelgium is one-have an opting out system where consent for donation is presumed if there is no contravening statement from the deceased.${ }^{13}$ In recent WHO guidelines on transplantation both systems are described but no specific system is recommended. A common policy would be preferable to increase efficiency in procuring, distributing, and using organs, but the exact design of the system will probably cause a lot of discussion.

The general assembly of the WHO twice unanimously issued resolutions calling for the prohibition of trade in human organs, and the Council of Europe has issued a similar recommendation. Most European legislatures have enacted laws to this effect, but a few countries, such as Ireland and the Netherlands, lack any legislation on organ donation.

\section{Euthanasia and assisted suicide}

Anyone working in medicine knows that euthanasia is practised even though it is prohibited in all European countries. It may well be called something else, but there is no doubt that the main purpose is to hasten the process of dying. The practice is publicly acknowledged in the Netherlands, although it is not legal. It is estimated that $1.8 \%$ of all deaths in the Netherlands are caused by the intentional administration of lethal

\section{Useful addresses and journals}

The Commission of the EC, the European Parliament, and the Council of Europe have information offices in all member states and can supply copies of the relevant documents.

European Association of Centers of Medical Ethics, Promenade de l'Alma 51, B-1200 Brussels, Belgium.

The European Society for the Philosophy of Medicine and Health Care, Secretary, Professor Dr Henk ten Have, Department of Ethics, Philosophy and History of Medicine, Catholic University of Nijmégan, Verlengde Groenestraat 75, PO Box 9101, 6500 HB Nijmegen, Netherlands.

The Standing Committee of Doctors of the EC, Ordem dos Médicos, Av Almirante Gago Coutinho 151,1700 Lisbon, Portugal.

The Bulletin of Medical Ethics, The fournal of Medical Ethics, Medicine and Ethics and the International Digest of Health Legislation cover developments in European medical ethics and law.

drugs. ${ }^{15}$ A Dutch member of the European parliament has proposed a resolution on the care of the terminally ill, which urges the commission to work for the introduction of voluntary euthanasia. ${ }^{15}$ This proposal is still under consideration. The legalisation of euthanasia has been rejected by the Standing Committee of Doctors of the EC in its declaration on euthanasia adopted in 1987 and by the World Medical Association in its declaration adopted at the 39 th world medical assembly in Madrid in 1987.

\section{The way forward}

The problems that will face doctors in the $\mathrm{EC}$ in the future are manifold, but two will give rise to ethical debates: changes in the relationship between doctors and patients, and problems with the just allocation of resources.

Patients will want to be more involved in the decisions about their treatment. They will want to be better informed, but they will still want to be able to lay the final responsibility for the decisions on their doctor. These seemingly incompatible demands must be incorporated in a new conception of the doctorpatient relationship. The main challenge for doctors will be to resist the intrusion of legal mechanisms without resisting the necessary changes in the relationship. Doctors will have to learn new ways of interacting with their patients. It may be that what patients want is not the emphasis on patient autonomy to the exclusion of all other values which has dominated the American scene. If cooperation, kindness, and friendship are allowed a role a good relationship is more likely to develop.

The allocation of health care resources will also become more pressing in the new Europe. The discussion in Britain about the differences between the poor north and the affluent south east is just a prelude to the European discussion about these problems. The social and regional differences highlighted in the Black report pale in comparison to the differences between the European regions. ${ }^{16}$ And the differences in the present EC will be greatly expanded if and when the new democracies in eastern Europe are allowed to join.

The committee of ministers of the Council of Europe has issued a recommendation on making medical care universally available, which specifies a wide range of health care that should be available to every citizen as a right. This ideal is not yet fulfilled in the poor regions 
of Europe, but the medical profession must actively work to achieve it. These challenges must be met individually, nationally, and at the European level. But it will not be an easy task. Not only are there cultural differences but the climate to discuss these issues varies between the member states. It is not possible to discuss freely euthanasia, prenatal screening, or abortion in all states. The European Society for the Philosophy of Medicine and Health Care (a neutral academic society) had to move its 1990 meeting from Germany to the Netherlands because of threats of disruption.

So unless we aim for the lowest common denominator we may find it much more dfficult to reach a common ethical policy than a common defence policy or a common monetary policy.

1 Office for Official Publications of the European Communities. 1992-the social dimension. Luxemburg: Office for Official Publications of the European Communities, 1990.

2 Holm S. New Danish law: human life begins at conception. 7 Med Ethics 1988;14:77-8.

3 Isambert F-A. Ethics committees in France. I Med Philos 1989;14:445-56.
4 Walters L. Commissions and bioethics. F Med Philos 1989;14:363-8. Glover J. Fertility and the family: the Glover report on reproductive technologies to the European commission. London: Fourth Estate, 1989.

6 Congregation for the Doctrine of Faith. Instruction on respect for human life in its origin and on the dignity of procreation. Vatican: Congregation for the Doctrin of Faith, 1987.

7 Council of Europe. Human artificial procreation. Strasburg: Council of Europe 1989.

8 Kasimba P. A summary of legislation relating to IVF. In: Singer $P$, Kuhse $H$, Buckle S, Dawson K, Kasimba P, eds. Embryo experimentation. Sydney: Cambridge University Press, 1990:227-36.

9 European Science Foundation. Report on genome research 1991. Southampton: European Science Foundation, 1991.

10 Rix BA. Should ethical concerns regulate science? The European experience with the human genome project. Bioethics 1991;5:250-6.

11 Conclusions of the council and the ministers for health, meeting within the council, on 16 May 1989 on AIDS. Official fournal of the European council, on 16 May 1989 on AIDS.

12 Conclusions of the council and of the ministers for health, meeting within the council, of 3 December 1990 on AIDS. Official foumal of the Europea Communities No C 1990 December 12:329/21-2.

13 Binamé G. Organ transplantation: a chronicle of a long-awaited law. International Digest of Health Legislation 1990;41:336-9.

14 Van der Maas PJ, van Delden JJM, Pijnenborg L, Looman CWN. Euthanasia and other medical decisions concerning the end of life. Lancel 1991;ii: $669-74$

15 Anonymous. European support for euthanasia? Bull Med Eth 1991;69:25-7.

16 Department of Health and Social Security. Inequalities in health: report of research working group. London: DHSS, 1980. (Black report.)

\title{
Leading for Health: responses
}

\section{Accountability and the NHS}

\author{
David J Hunter
}

This is the third in a series of articles responding to the questions raised by the BMA's document, "Leading for Health." The document looks well beyond the coming British election and raises questions about health and health care that will be on the agenda of many countries into the next century.

Nuffield Institute for Health Services Studies, University of Leeds, Leeds LS2 9PL

David J Hunter, PHD, director

$B M \mathcal{F} 1992 ; 304: 436-8$
At various times throughout its history the NHS has been accused of being both centralised, monolithic, and bureaucratic ${ }^{12}$ and decentralised, fragmented, and insufficiently accountable. ${ }^{3}$ At the centre of this paradox is the dilemma of accountability, an issue that is discussed in terms of local and central accountability in Leading for Health: a BMA Agenda for Health. ${ }^{+}$

At a formal level the issue of accountability is deceptively clear and unequivocal. ${ }^{5}$ Health ministers and their officials in the four health departments of the United Kingdom are accountable to parliament for all that happens in the NHS. The health authorities are the agents of the central department and its ministerial head. But while the theory of accountability may be clear, its practice is decidedly less so.

\section{The chain of command}

The vexed issue of accountability has exercised academic observers, former permanent secretaries, and official committees for many years. All are critical of current arrangements. The 1979 Royal Commission on the NHS concluded that "detailed ministerial accountability for the NHS is largely a constitutional fiction." "The report described the gap which exists between the formal, detailed accountability enshrined in the constitutional conventions governing the NHS and the realities of managing what in practice amounts to an extremely complex and diverse set of activities.

The present NHS reforms, as with earlier reorganisations, do little to resolve this longstanding dilemma. The white paper Working for Patients ${ }^{7}$ is at pains to emphasise the importance of decentralised decision making in order to free managers to be more responsive to local preferences and the views of users. The purchaser-provider separation, managed competition, and the notion of money following the patient are intended to achieve these aims.

But the white paper betrays an ambivalence evident in successive NHS reforms when it refers to the "chain of command" operating from the coal face of health service delivery to parliament via the secretary of state for health. It is this chain which threatens attempts to unshackle management from political constraints. Some believe this to be at the root of many of the NHS's difficulties. Sir Roy Griffiths expressed concern about the issue and attempted to solve it in 1983 by creating a management board (now the NHS Management Executive) within the Department of Health so as to engineer a separation between political and managerial accountability "to achieve consistency and drive over the long term." "But a neat distinction between political and managerial accountability, sometimes portrayed as a split between policy making and implementation, is not sustainable in practice. Political processes do not generate precise, clear cut objectives or the criteria necessary for effective managerial accountability to be achieved. ${ }^{9}$

\section{Finding a balance}

There are other features of the NHS reforms which challenge prevailing notions of accountability. In particular, there is the position of NHS trusts, which may enjoy freedom from local health authority control, though they remain accountable to the secretary of state. If trusts grow in number it will not be realistic for the centre to be directly responsible for them. The NHS Management Executive is currently searching for a solution to this problem that is compatible with current conventions.

A little known report published by the House of Commons Public Accounts Committee in July 1991 nicely illustrates the continuing dilemma in the context of the management of the NHS in Northern Ireland. ${ }^{10}$ The committee is unequivocal in its view that as an accounting officer the chief executive of the health and personal social services, Northern Ireland management executive, is personally responsible for the funds voted by parliament and entrusted to his care. The committee was "greatly concerned" by the chief executive's answers to its questions and by his arguments that as "day to day management responsibility had been delegated to the Boards . . . [this] absolved him from 